\title{
Association between risk of brucellosis and genetic variations in MicroRNA-146a
}

\author{
Sima Kazemi ${ }^{1}$, Saeid Afshar ${ }^{2}$, Manoochehr Karami ${ }^{3}$, Massoud Saidijam², Fariba Keramat ${ }^{4}$, \\ Seyed Hamid Hashemi ${ }^{4}$ and Mohammad Yousef Alikhani ${ }^{1,4^{*}}$
}

\begin{abstract}
Background: Single nucleotide polymorphisms (SNPs) are the most common types of DNA changes in the human genome that leading to phenotypic differences in humans. MicroRNAs (miRNAs) are usually affected by various bacterial infections, and they are involved in controlling the immune responses. MicroRNA-146a (miR-146a) plays an essential role in the development of infectious and inflammatory diseases. The aim of the present study was to investigate the association between risk of brucellosis and genetic variations in miR-146a.

Methods: This case-control study was conducted on 108 Brucellosis patients and 108 healthy controls. We genotyped two SNPs (rs2910164 and rs57095329) of the miR-146a using tetra-primer amplification refractory mutation system-polymerase chain reaction (T-ARMS-PCR) and restriction fragment length polymorphism-polymerase chain reaction (RFLP-PCR) methods.

Results: The rs 2910164 SNP was significantly associated with brucellosis in co-dominant $[\mathrm{OR}=4.27,95 \% \mathrm{Cl}=(2.35-$ $7.79, P=0.001]$ and dominant $[\mathrm{OR}=3.52,95 \% \mathrm{Cl}=(1.97-6.30, P=0.001]$ models. Co-dominant $(P=0.047)$ and recessive $(P=0.018)$ models were significant at position rs57095329 between the two groups of patient and healthy. The A C haplotype (rs2910164 and rs57095329) was associated with brucellosis in the assessed population [OR (95\% $\mathrm{Cl})=1.98(1.22-3.20), P=0.0059]$.

Conclusions: Consequently, our study demonstrated significant differences in genotype and haplotype frequencies of miR-146a variants between brucellosis patients and controls. Further studies on the larger sample sizes are required to verify the observed associations.
\end{abstract}

Keywords: Brucellosis, Genetic variations, miR-146a

\section{Background}

One of the highly noticeable zoonotic diseases globally is brucellosis, particularly in developing countries caused by the genus Brucella [1-3]. Bacteria are transmitted to humans by consumption of unpasteurized dairy products, direct contact with the various components of the infected animal, or inhalation of aerosols [4]. The prevalence of human diseases in endemic areas is more than

\footnotetext{
*Correspondence: alikhani43@yahoo.com; alikhani@umsha.ac.ir

${ }^{4}$ Brucellosis Research Center, Hamadan University of Medical Sciences,

Hamadan, Iran
}

Full list of author information is available at the end of the article
10 per 100,000 population. Hamadan province, in the western part of Iran, has the highest incidence in the country, with 130 cases per 100,000 population [5]. Brucellosis causes considerable economic losses in numerous countries every year by damage to livestock via reduced fertility, abortion, and reduction in meat production, and milk [6]. MicroRNAs (miRNAs) are a type of evolutionary conserved small single-stranded non-coding RNAs which control the target gene expression negatively via mRNA degradation or translational expression at the post transcriptional level [7-9]. Furthermore, a miRNA is capable of modulating the expression of several mRNAs, 
and one mRNA can be targeted by many miRNAs [10]. MiRNAs play a crucial regulatory role in extensive types of biological processes such as cell differentiation, early evolution, autophagy, metabolism, apoptosis, proliferation, DNA repair, and immune responses [10-12]. MicroRNAs have also been demonstrated to have a major role during infection by diverse pathogens, including viruses, parasites, and bacteria [13-15]. Additionally, the potential importance of miRNAs in the immune response to intracellular and extracellular pathogens such as $\mathrm{Myco-}$ bacteria spp., Helicobacter pylori, Salmonella enterica, Listeria monocytogenes, Staphylococcus aureus, Pseudomonas aeruginosa, Citrobacter rodentium, Francisella spp., chlamydia spp., Burkholderia pseudomallei and Shigella flexneri has been demonstrated [16-25]. Control of miRNAs has been identified as a key regulatory factor in the immune system [26]. Single nucleotide polymorphisms (SNPs) represent the most abundant genetic variation in the entire human genome [27]. Researches have shown that genetic alterations in miRNA sequences can affect primary miRNA (pri-miRNA) and precursor miRNA (pre-miRNA) processing and thus alter miRNA expression [28]. Following changes in the polymorphisms of these molecules, they may have possible consequences for the regulation of gene expression, and the progress of the diseases [29]. MiR-146a, is one of the highly conserved miRNAs, which is recognized for its crucial balancing of the inflammation and immune responses [30], and bacterial infections, especially mycobacteria [31-33]. Rs2910164 and rs57095329 are the two most remarkable and widely seen SNP in miR-146a. They can affect the level of mature miR-146a and are related to different types of cancer, many inflammation-associated diseases, and important neurological and infectious diseases such as systemic lupus erythematosus (SLE), Behcet's disease, sepsis, rheumatoid arthritis, tuberculosis (TB), hepatitis, Alzheimer's disease (AD), and multiple sclerosis [33-41]. The miR-146a polymorphism rs2910164 is located on chromosome 5q33 [42]. Polymorphism rs2910164 (G > C) in pre-miR146a, leads to a change from a G:U pair to a $\mathrm{C}: \mathrm{U}$ mismatch in its stem region $[40,43]$. The A/G polymorphism of rs57095329 in the miR-146a is specified to be located in the promoter region [36]. It is also demonstrated that the level of mature miR-146a is reduced by lowering the transcription factor binding Vets oncogenehomolog-1 which was related to the risk of SLE [36]. MiR-146a plays a pivotal role in regulating the immune responses. Therefore, there may be an association between the SNP molecule and the immune responses to pathogens and the risk of infectious diseases like brucellosis [44]. To date, there are no data showing the relevance between miR-146a polymorphism with brucellosis disease. Therefore, we conducted an evaluation study to find the relationship between polymorphisms of miR-146a (rs57095329 and rs2910164) with brucellosis patients as well as healthy controls in Hamadan province's population, the west of Iran.

\section{Methods \\ Study subjects}

This case-control study included 108 brucellosis patients and 108 controls recruited from the Farshchian's Hospital of Hamadan between February 2018 and August 2019. Diagnosis of the disease was confirmed according to the following criteria: (1) clinical manifestations such as arthralgia, weight loss, malaise, fever, hepatomegaly, focal complication, splenomegaly, and sweating (2) detection of specific antibody titers in the serum samples of individuals who referred to the Infectious Diseases Ward, Farshchian's Hospital, using Wright titer $\geq 1 / 160$ and 2-mercaptoethanol test $(2 \mathrm{ME}) \geq 1 / 80$, and 3 ) isolation of Brucella spp. in blood, using a BACTEC blood culture system (9050 BD Company, U.S.A.), which is a fully automated microbiology growth and detection system designed to detect microbial growth from blood specimens or PCR method to identify the Brucella isolates, targeting the bcsp31 gene coding a $31-\mathrm{kDa}$ outer membrane protein Brucella spp.[45]. Exclusion criteria in this study were inflammatory diseases including cardiovascular diseases, severe hematological, gastrointestinal, neurological diseases, patients with the deficiency of glucose 6-phosphate dehydrogenase (G6PD), or pregnant women or people with diseases such as psoriasis and porphyria [46].

The control group consisted of individuals without brucellosis, also evaluated with any antibody to brucellosis in serological tests. Healthy subjects were selected from the same geographical location of the patients. The study protocol was approved by the Ethics Committee of Hamadan University of Medical Sciences, Hamadan, Iran (Ethical committee ID: IR.UMSHA.REC.1397. 857).

\section{DNA extraction}

Genomic DNA was extracted from peripheral whole blood samples from patients and controls by the salting out technique [47]. All DNA samples were dissolved in water and stored at $-20^{\circ} \mathrm{C}$ for future use.

\section{Genotyping}

SNPs of the miR-146a gene (rs2910164 G/C and rs57095329 A/G) were assessed by tetra-primer amplification refractory mutation system-polymerase chain reaction (T-ARMS-PCR) and restriction fragment length polymorphism-polymerase chain reaction (RFLP-PCR), respectively. The primers and PCR conditions used for the mir-146a (rs2910164 G/C) are as 
follows: FO (Outer): 5'GGCCTGGTCTCCTCCAGA TGTTTAT3', RO: 5'ATACCTTCAGAGCCTGAGACT CTGCC3', FI (Inner) (C allele): 5'ATGGGTTGTGTC AGTGTCAGACGTC3', RI (Inner) (G allele): 5'GAT ATCCCAGCTGAAGAACTGAATTTGAC $3^{\prime}$ [48]. The PCR assay was performed using commercially available PCR premix (PCR 2X Taq premix Mastermix; (Ampliqon, Denmark). Briefly, $100 \mathrm{ng} / \mu \mathrm{L}$ templates DNA, $1 \mu \mathrm{L}$ of each primer $(10 \mathrm{pmol} / \mu \mathrm{L})$ were added to PCR PreMix at a final volume of $20 \mu \mathrm{L}$. The thermocycling conditions for rs2910164 G/C: $5 \mathrm{~min}$ at $95{ }^{\circ} \mathrm{C}$, followed by 30 cycles of $30 \mathrm{~s}$ at $95{ }^{\circ} \mathrm{C}$, annealing temperatures at $62{ }^{\circ} \mathrm{C}$ for $30 \mathrm{~s}$, extension at $72{ }^{\circ} \mathrm{C}$ for $30 \mathrm{~s}$ and a final extension step in $72{ }^{\circ} \mathrm{C}$ for $10 \mathrm{~min}$ [48]. PCR products were separated by electrophoresis on $2 \%$ agarose gel. The primers used in the RFLP-PCR reaction (rs57095329 A/G) included 5'-GGGGCTGCGGAG AGTACCG- $3^{\prime}$ and $5^{\prime}$-GGACCCTCTTGCAGCACG TGTC-3' [49] and the restriction enzyme was MspI (Fermentase, Lithuania). PCR program for (rs57095329 A/G) was as follow: Initial denaturalization at $95^{\circ} \mathrm{C}$ for 5 min, followed by 30 cycles of denaturation at $95{ }^{\circ} \mathrm{C}$, $30 \mathrm{~s}$, annealing for $30 \mathrm{~s}$ at $60{ }^{\circ} \mathrm{C}$, extension at $72{ }^{\circ} \mathrm{C}$ for $30 \mathrm{~s}$ and a final extension step at $72{ }^{\circ} \mathrm{C}$ for $5 \mathrm{~min}$. The digestion products were identified by silver staining
[50]. Finally, $10 \%$ of the total samples randomly chosen to validate were sent for sequencing.

\section{Statistical analysis}

Statistical assessment was performed using version 16 of SPSS. Even though, the Hardy-Weinberg equilibrium (HWE) was not maintained in both SNPs, the Expectation-Maximization (EM) algorithm was used in R software to calculate the frequency of alleles. The linkage disequilibrium (LD) between rs2910164 and rs57095329 were appraised by measurement of D' and r values. Associations between the brucellosis and the rs2910164/ rs57095329 SNP were addressed by calculating odds ratios (ORs) and 95\% confidence intervals (CI) in haplotype as well as in alleles, recessive, dominant, and codominant inheritance models. $P$ values less than 0.05 were regarded as significant.

\section{Results}

Characteristics of the study population

The demographic characteristics of patients and control individuals are shown in Table 1. In this study consisted of 108 brucellosis patients ( 73 men and 35 women), (age range $15-87$ years and mean $\pm \mathrm{SD}=15.19 \pm 44.55$ ) and 108 healthy subjects as a control group (85

Table 1 Demographic characteristics of brucellosis patients and control subjects

\begin{tabular}{|c|c|c|c|}
\hline Factors & Case group $n=108$ & Control group $n=108$ & $P$-value \\
\hline \multicolumn{4}{|l|}{ Age } \\
\hline Mean $\pm S D$ & $15.19 \pm 44.55$ & $10.448 \pm 37.38$ & $<0.001$ \\
\hline \multirow[t]{2}{*}{ Range (years) } & $15-87$ & $19-65$ & \\
\hline & No (\%) & No (\%) & \\
\hline \multicolumn{4}{|l|}{ Sex } \\
\hline Men & $73(67.6)$ & $85(78.7)$ & 0.091 \\
\hline Women & $35(32.4)$ & $23(21.3)$ & \\
\hline \multicolumn{4}{|l|}{ Habitat } \\
\hline Urban & $17(15.7)$ & (71.3) 77 & $<0.001$ \\
\hline Rural & $91(84.3)$ & $31(28.7)$ & \\
\hline \multicolumn{4}{|c|}{ History of non-pasteurized dairy products } \\
\hline Yes & $87(80.6)$ & - & $<0.001$ \\
\hline No & $21(80.6)$ & $108(100)$ & \\
\hline \multicolumn{4}{|c|}{ History of contact with livestock } \\
\hline Yes & $89(82.4)$ & - & $<0.001$ \\
\hline No & $19(17.6)$ & $108(100)$ & \\
\hline \multicolumn{4}{|c|}{ History of Brucellosis } \\
\hline Yes & $29(26.9)$ & - & $<0.001$ \\
\hline No & $79(73.1)$ & $108(100)$ & \\
\hline \multicolumn{4}{|c|}{ History of brucellosis treatment } \\
\hline Yes & $28(25.9)$ & - & $<0.001$ \\
\hline No & $80(74.1)$ & $108(100)$ & \\
\hline
\end{tabular}


men and 23 women), (age range 19-65 years and mean $\pm \mathrm{SD}=10.448 \pm 37.38$ ). There was a significant difference in age in both patient and healthy groups $(P<0.001)$. No significant difference in sex was observed between the two groups $(P=0.091)$. Besides, there was a significant difference in the habitat, consumption history of unpasteurized dairy products, history of contact with livestock, history of brucellosis and history of brucellosis treatment between patient, and control groups. (All $P<0.001)$.

\section{Association of single nucleotide polymorphisms in miR-146a with risk of brucellosis}

The genotypes and alleles analyses of miR-146a SNP in patient and control subjects are shown in Table 2. At position rs2910164, the frequency of GC genotypes was higher in the control group compared to the patient group, while the frequency of genotype GG was higher in the patient group than in the control group. The rs2910164, co-dominant $[\mathrm{OR}=4.27,95 \% \mathrm{CI}=2.35-7.79$, $\mathrm{P}=0.001]$ and dominant $[\mathrm{OR}=3.52,95 \% \mathrm{CI}=1.97-6.30$, $\mathrm{P}=0.001]$ models were statistically significantly different between patients and controls. The rs57095329, codominant $[\mathrm{OR}=0.63,95 \% \mathrm{CI}=0.17-2.29, P=0.047]$ and recessive $(P=0.018)$ models were significantly different between the patient and healthy groups. Analysis of alleles frequency of rs2910164 and rs57095329 revealed no statistically significant differences between patients and controls.

\section{Haplotype analysis}

The rs2910164 and rs57095329 SNPs were not in LD in the assessed population $\left(D^{\prime}=0.41, r=-0.06\right)$. The A C haplotype (rs2910164 and rs57095329) increased the risk of brucellosis in the assessed population [OR (95\% CI) $=1.98(1.22-3.20), P=0.0059$ ]. Table 3 demonstrates the haplotypes in cases and controls.

\section{Discussion}

In the current study, we examined the effects of two polymorphisms in miR-146a among patients with brucellosis. Many studies have explored the role of miRNA regulation in the immune response against bacteria. Taganov et al. [51] first described miRNA-146a. MiR$146 \mathrm{a} / \mathrm{b}, \mathrm{miR}-21$, miR-155, and the let-7 family are the most extensively studied miRNAs in innate immune response, regulating several steps of the related pathways [52-54]. These miRNAs activate Toll-like receptors (TLRs). TLRs play crucial roles in the immune system by recognizing pathogen-associate molecular pattern (PAMP) derive from various microbes. Specifically, these and other miRNAs activate some of the components of TLR signaling, leading to regulating the extent and timing of the inflammatory response [55]. Genetic

Table 2 Genotype and allele frequencies distribution in patients with brucellosis and controls

\begin{tabular}{|c|c|c|c|c|c|}
\hline Model & Genotype & Cases $(n=108)$ No. $(\%)$ & $\begin{array}{l}\text { Controls }(n=108) \text { No. } \\
(\%)\end{array}$ & OR $(95 \% \mathrm{Cl})$ & P-value \\
\hline \multicolumn{6}{|c|}{ MiR-146a rs2910164 } \\
\hline \multirow[t]{2}{*}{ Allele } & $C$ & $31(28.7)$ & $43(39.8)$ & 1 & 0.085 \\
\hline & G & $77(71.3)$ & $65(60.2)$ & $1.64(0.93-2.89)$ & \\
\hline \multirow[t]{3}{*}{ Co-dominant } & GG & $57(52.8)$ & $26(24.1)$ & 1.00 & $<0.0001$ \\
\hline & GC & $40(37)$ & $78(72.2)$ & $4.27(2.35-7.79)$ & \\
\hline & $\mathrm{CC}$ & $11(10.2)$ & $4(3.7)$ & $0.80(0.23-2.74)$ & \\
\hline \multirow[t]{2}{*}{ Dominant } & $\mathrm{G} / \mathrm{G}$ & $57(52.8)$ & $26(24.1)$ & 1.00 & $<0.0001$ \\
\hline & GC-CC & $51(47.2)$ & $82(75.9)$ & $3.52(1.97-6.30)$ & \\
\hline \multirow[t]{2}{*}{ Recessive } & GG-GC & $97(89.8)$ & $104(96.3)$ & 1.00 & 0.056 \\
\hline & $\mathrm{CC}$ & $11(10.2)$ & $4(3.7)$ & $0.34(0.10-1.10)$ & \\
\hline \multicolumn{6}{|c|}{ MiR-146a rs57095329 } \\
\hline \multirow[t]{2}{*}{ Allele } & A & $104(96.3)$ & $100(92.6)$ & 1 & 0.235 \\
\hline & G & $4(3.7)$ & $8(7.4)$ & $2.08(0.60-7.125)$ & \\
\hline \multirow[t]{3}{*}{ Co-dominant } & $\mathrm{AA}$ & $98(90.7)$ & $104(96.3$ & 1.00 & 0.047 \\
\hline & $A G$ & $6(5.6)$ & $4(3.7)$ & $0.63(0.17-2.29)$ & \\
\hline & GG & $4(3.7)$ & $0(0)$ & $0.00(0.00-\mathrm{NA})$ & \\
\hline \multirow[t]{2}{*}{ Dominant } & AA & $98(90.7)$ & $104(96.3)$ & 1.00 & 0.092 \\
\hline & AG-GG & $10(9.3)$ & $4(3.7)$ & $0.38(0.11-1.24)$ & \\
\hline \multirow[t]{2}{*}{ Recessive } & $A A-A G$ & $104(96.3)$ & $108(100)$ & 1.00 & 0.018 \\
\hline & GG & $4(3.7)$ & $0(0)$ & 0.00 (0.00-NA) & \\
\hline
\end{tabular}


Table 3 Haplotypes of rs2910164 and rs57095329 SNP in patients with brucellosis and controls

\begin{tabular}{llccll}
\hline rs2910164 & rs57095329 & Patients \% & Controls \% & OR (95\% Cl) & P-value \\
\hline G & A & 66.08 & 58.79 & 1.00 & - \\
C & A & 27.44 & 39.35 & $1.98(1.22-3.20)$ & 0.0059 \\
G & G & 5.21 & 1.39 & $0.57(0.19-1.67)$ & 0.3 \\
C & G & 1.27 & 0.46 & 1
\end{tabular}

Global haplotype association P-value: 0.0069

mutations in miRNAs greatly affect the development of the immune system and immune response and can lead to autoimmune, inflammatory, and cancer diseases [29]. To date, no studies have been published on the association of miR-146a polymorphism and brucellosis. We reported that at position rs2910164, co-dominant and dominant models differed significantly between the case and control groups also there was no significant difference in the alleles frequencies of rs2910164 between cases and controls. Several studies have provided evidence that there was no significant difference in the distribution of the miR-146a (rs2910164 G/C) genotypes in various diseases including $\mathrm{TB}$, gastric cancer, coronary artery, and colon cancer between the patient and control groups [56-59]. A study in Brazil showed that the mutation of SNP G > C (rs2910164), and especially the C allele, was associated with susceptibility to leprosy [60]. Another study suggested that miR-146a plays an important role in rheumatoid arthritis [61]. In a study of hepatitis B patients in China, they examined the changes of miRNA polymorphisms in response to hepatitis B vaccination antibody and they found that there was a significant difference in the frequency of the position of rs2910164 between responders and non-responders, also the CC genotype resulted in a 1.74-fold increase compared to the other genotypes [62]. In Japan, Song et al. [63] found that people with rs2910164 CC genotype had a significantly increased risk of intestinal metaplasia and dysplasia and rs2910164 C allele was associated with an increased risk of intestinal metaplasia and dysplasia only among individuals infected with Helicobacter pylori. In our study of this situation, the frequency of GG and CC genotypes is higher in patients than in controls, while the prevalence of GC genotypes is higher in controls than in patients. In the present project, analysis of allele's frequency of rs57095329 A/G revealed no statistically significant differences between patients, and controls and the rs57095329, co-dominant and recessive models were significantly associated between the patient and healthy groups. Shao et al. [35] in sepsis, showed that the $\mathrm{C}$ allele and the $\mathrm{CC}$ genotype were more prevalent at position rs2910164. However, no significant difference was found between allele and genotype at position rs57095329.
In 2020 in the Indian population determined that the GC genotype had a significant influence on the susceptibility to colorectal cancers [64]. A previous study [65], found significant differences in the allele $\mathrm{G}$ and $\mathrm{CC}$ genotype of miR-146 C>G SNP between the pulmonary TB patients and healthy controls in the Kazak population, while in the Uygur population there were no significant differences in the frequencies of alleles and genotypes of miR-146a. The results of Damodaran et al. [66] a study of case-control in India by examining two-position rs2910164 and rs57095329 in miR-146a reported that the AG genotype at rs57095329 in the control group was significantly higher than in the patient group, while the rs2910164 position had nothing to do with the prostate cancer. In lupus, participants with G (rs57095329) allele had reduced expression of the miR-146a [36]. In contrast to our study based on the results of Zhou et al. [34], no significant difference was observed between Vogt-Koyanagi-Harada (VKH) patients in both position rs2910164 and rs57095329 However, in people with Behçet's disease, the rs2910164 CC genotype, and C allele were significantly reduced compared to the control group. It is worth mentioning that there was a significant difference in the A C haplotype between the patients and the controls. In numerous reports demonstrated that there are no significant differences between haplotypes of rs2910164 and rs57095329 in the patient group compared to the control group [41, 67]. Cui et al. [67] showed that the rs57095329 polymorphism in the promoter region of miR-146a is involved in the risk of drug-resistant epilepsy (DRE), and the rs57095329 A allele was found to be associated with a reduced risk of seizures frequency in DRE patients. However, the rs2910164 variant was not associated with epilepsy. In $\mathrm{AD}$, determined that the AA genotype of the rs57095329 polymorphism was associated with an increased risk for cognitive decline in patients [41].

\section{Conclusion}

In the current study, we demonstrated that the dominant and co-dominant inheritance models of rs2910164 associated with brucellosis. As well as dominant and recessive models were associated with brucellosis at position rs57095329 and A C haplotype (rs2910164 and 
rs57095329) was associated against brucellosis. Further studies on the larger sample sizes are required to verify the observed associations. Besides, functional studies are required to identify fundamental mechanisms.

\author{
Abbreviations \\ T-ARMS-PCR: Tetra-primer amplification refractory mutation system-polymer- \\ ase chain reaction; RFLP-PCR: Restriction fragment length polymorphism- \\ polymerase chain reaction; SNPs: Single nucleotide polymorphisms; miRNAs: \\ MicroRNAs.
}

\section{Acknowledgements}

The authors would like to acknowledge the Vice-chancellor of Research of Hamadan University of Medical Sciences, Hamadan, Iran for supporting this study.

\section{Authors' contributions}

MYA designed and supervised the study. MS and SA and MYA performed data interpretation. SK and MYA were responsible for data collection and doing experiments. FK and SHH performed clinical examination. MK analyzing the statistical results of the study. All authors read and approved the final manuscript.

\section{Funding}

This study was supported by funding from the Hamadan University of medical sciences, Hamadan, IRAN, under Grant number 9711307368

\section{Availability of data and materials}

The datasets used and/or analyzed during the current study available from the corresponding author on reasonable request.

\section{Declarations}

\section{Ethics approval and consent to participate}

The study was approved by the Institutional Review Board of Hamadan University of Medical Sciences (Ethical approval code: IR.UMSHA.REC.1397.857). Ethical Review Board approved informed consent taken from all the participants. All methods were carried out in accordance with relevant guidelines and regulations/Declaration of Helsinki.

\section{Consent for publication}

Not applicable.

\section{Competing interests}

None of the authors have a conflict of interests.

\section{Author details}

'Department of Microbiology, Faculty of Medicine, Hamadan University of Medical Sciences, Hamadan, Iran. ${ }^{2}$ Research Center for Molecular Medicine, School of Medicine, Hamadan University of Medical Sciences, Hamadan, Iran. ${ }^{3}$ Department of Biostatistics and Epidemiology, School of Public Health, Hamadan University of Medical Sciences, Hamadan, Iran. ${ }^{4}$ Brucellosis Research Center, Hamadan University of Medical Sciences, Hamadan, Iran.

\section{Received: 29 March 2021 Accepted: 8 October 2021}

Published online: 16 October 2021

\section{References}

1. Xavier M, Paixão T, Poester F, Lage A, Santos R. Pathological, immunohistochemical and bacteriological study of tissues and milk of cows and fetuses experimentally infected with Brucella abortus. J Comp Pathol. 2009;140(2-3):149-57.

2. Pappas G, Panagopoulou P, Christou L, Akritidis N. Biological weapons. Cell Mol Life Sci CMLS. 2006;63(19-20):2229-36.
3. Atluri VL, Xavier MN, De Jong MF, Den Hartigh AB, Tsolis RM. Interactions of the human pathogenic Brucella species with their hosts. Annu Rev Microbiol. 2011;65:523-41.

4. Xavier MN, Paixao TA, den Hartigh AB, Tsolis RM, Santos RL. Pathogenesis of Brucella spp. Open Veterinary Sci J 2010; 4(1).

5. Hashemi SH, Keramat F, Ranjbar M, Mamani M, Farzam A, Jamal-Omidi S. Osteoarticular complications of brucellosis in Hamedan, an endemic area in the west of Iran. Int J Infect Dis. 2007;1 1(6):496-500.

6. Asiimwe BB, Kansiime C, Rwego IB. Risk factors for human brucellosis in agro-pastoralist communities of south western Uganda: a case-control study. BMC Res Notes. 2015;8(1):405.

7. Lee RC, Feinbaum RL, Ambros V. The C. elegans heterochronic gene lin-4 encodes small RNAs with antisense complementarity to lin-14. Cell. 1993;75(5):843-54.

8. Kong YW, Ferland-McCollough D, Jackson TJ, Bushell M. microRNAs in cancer management. Lancet Oncol. 2012;13(6):e249-58.

9. Kataoka M, Wang D-Z. Non-coding RNAs including miRNAs and IncRNAs in cardiovascular biology and disease. Cells. 2014;3(3):883-98.

10. Li Z, Rana TM. Therapeutic targeting of microRNAs: current status and future challenges. Nat Rev Drug Discovery. 2014;13(8):622-38.

11. Kunej T, Godnic I, Horvat S, Zorc M, Calin GA. Cross talk between microRNA and coding cancer genes. Cancer J (Sudbury, Mass). 2012;18(3):223

12. Baranwal S, Alahari SK. miRNA control of tumor cell invasion and metastasis. Int J Cancer. 2010;126(6):1283-90.

13. Staedel C, Darfeuille F. Micro RNA s and bacterial infection. Cell Microbiol. 2013;15(9):1496-507.

14. Eulalio A, Schulte L, Vogel J. The mammalian microRNA response to bacterial infections. RNA Biol. 2012:9(6):742-50.

15. Cullen BR. Viruses and microRNAs: RISCy interactions with serious consequences. Genes Dev. 2011:25(18):1881-94.

16. Zhou X, Li X, Ye Y, Zhao K, Zhuang Y, Li Y, Wei Y, Wu M. MicroRNA$302 \mathrm{~b}$ augments host defense to bacteria by regulating inflammatory responses via feedback to TLR/IRAK4 circuits. Nat Commun. 2014;5(1):1-14

17. Sunkavalli U, Aguilar C, Silva RJ, Sharan M, Cruz AR, Tawk C, Maudet C, Mano M, Eulalio A. Analysis of host microRNA function uncovers a role for miR-29b-2-5p in Shigella capture by filopodia. PLoS Pathog. 2017;13(4):e1006327.

18. Rothchild AC, Sissons JR, Shafiani S, Plaisier C, Min D, Mai D, Gilchrist M, Peschon J, Larson RP, Bergthaler A. MiR-155-regulated molecular network orchestrates cell fate in the innate and adaptive immune response to Mycobacterium tuberculosis. Proc Natl Acad Sci. 2016;113(41):E6172-81.

19. Oertli M, Engler DB, Kohler E, Koch M, Meyer TF, Müller A. MicroRNA-155 is essential for the T cell-mediated control of Helicobacter pylori infection and for the induction of chronic Gastritis and Colitis. J Immunol. 2011;187(7):3578-86

20. Mirzaei R, Mohammadzadeh R, Mirzaei H, Sholeh M, Karampoor S, Abdi M, Alikhani MY, Kazemi S, Ahmadyousefi Y, Jalalifar S. Role of microRNAs in Staphylococcus aureus infection: potential biomarkers and mechanism. IUBMB Life 2020.

21. Lou J, Wang Y, Zhang Z, Qiu W. MiR-20b inhibits mycobacterium tuberculosis induced inflammation in the lung of mice through targeting NLRP3. Exp Cell Res. 2017;358(2):120-8.

22. Kumar M, Sahu SK, Kumar R, Subuddhi A, Maji RK, Jana K, Gupta P, Raffetseder J, Lerm M, Ghosh Z. MicroRNA let-7 modulates the immune response to Mycobacterium tuberculosis infection via control of A20, an inhibitor of the NF-KB pathway. Cell Host Microbe. 2015;17(3):345-56.

23. Jingjing Z, Nan Z, Wei W, Qinghe G, Weijuan W, Peng W, Xiangpeng W. MicroRNA-24 modulates Staphylococcus aureus-induced macrophage polarization by suppressing CHI3L1. Inflammation. 2017:40(3):995-1005.

24. Izar B, Mannala GK, Mraheil MA, Chakraborty T, Hain T. microRNA response to Listeria monocytogenes infection in epithelial cells. Int J Mol Sci. 2012:13(1):1173-85

25. Aguilar C, Mano M, Eulalio A. MicroRNAs at the host-bacteria interface: host defense or bacterial offense. Trends Microbiol. 2019;27(3):206-18.

26. Jia Y, Wei Y. Modulators of MicroRNA function in the immune system. Int J Mol Sci. 2020;21(7):2357.

27. Butler JM. Single nucleotide polymorphisms and applications. Advanced Topics in Forensic DNA Typing, Academic Press, California, USA 2012:347-369. 
28. Bosetti C, Levi F, Rosato V, Bertuccio P, Lucchini F, Negri E, La Vecchia C. Recent trends in colorectal cancer mortality in Europe. Int J Cancer. 2011;129(1):180-91.

29. O'connell RM, Rao DS, Chaudhuri AA, Baltimore D. Physiological and pathological roles for microRNAs in the immune system. Nat Rev Immu nol. 2010;10(2):111-22.

30. Zilahi E, Tarr T, Papp G, Griger Z, Sipka S, Zeher M. Increased microRNA$146 \mathrm{a} / \mathrm{b}$, TRAF6 gene and decreased IRAK1 gene expressions in the peripheral mononuclear cells of patients with Sjögren's syndrome. Immunol Lett. 2012;141(2):165-8.

31. Spinelli SV, Diaz A, D'Attilio L, Marchesini MM, Bogue C, Bay ML, Bottasso OA. Altered microRNA expression levels in mononuclear cells of patients with pulmonary and pleural tuberculosis and their relation with components of the immune response. Mol Immunol. 2013:53(3):265-9.

32. Saba R, Sorensen DL, Booth SA. MicroRNA-146a: a dominant, negative regulator of the innate immune response. Front Immunol. 2014;5:578.

33. Liu Y, Wang $X$, Jiang J, Cao Z, Yang B, Cheng X. Modulation of T cell cytokine production by miR-144* with elevated expression in patients with pulmonary tuberculosis. Mol Immunol. 2011;48(9-10):1084-90.

34. Zhou Q, Hou S, Liang L, Li X, Tan X, Wei L, Lei B, Kijlstra A, Yang P. MicroRNA-146a and Ets-1 gene polymorphisms in ocular Behçet's disease and Vogt-Koyanagi-Harada syndrome. Ann Rheum Dis. 2014;73(1):170-6.

35. Shao Y, Li J, Cai Y, Xie Y, Ma G, Li Y, Chen Y, Liu G, Zhao B, Cui L. The functional polymorphisms of miR-146a are associated with susceptibility to severe sepsis in the Chinese population. Mediators Inflammation 2014; 2014

36. Luo X, Yang W, Ye D-Q, Cui H, Zhang Y, Hirankarn N, Qian X, Tang Y, Lau YL, De Vries N. A functional variant in microRNA-146a promoter modulates its expression and confers disease risk for systemic lupus erythematosus. PLoS Genet. 2011;7(6):e1002128.

37. Li Y, Du C, Wang W, Ma G, Cui L, Zhou H, Tao H, Yao L, Zhao B, Li K. Genetic association of MiR-146a with multiple sclerosis susceptibility in the Chinese population. Cell Physiol Biochem. 2015;35(1):281-91.

38. Li L, Chen XP, Li YJ. MicroRNA-146a and human disease. Scand J Immunol. 2010;71(4):227-31.

39. Labib DA, Shaker OG, El Refai RM, Ghoniem SA, Elmazny A. Association between miRNA-146a and polymorphisms of its target gene, IRAK1 regarding susceptibility to and clinical features of systemic lupus erythematous and multiple sclerosis. Lab Med. 2019;50(1):34-41.

40. Hung P-S, Chang K-W, Kao S-Y, Chu T-H, Liu C-J, Lin S-C. Association between the rs2910164 polymorphism in pre-mir-146a and oral carcinoma progression. Oral Oncol. 2012:48(5):404-8.

41. Cui L, Li Y, Ma G, Wang Y, Cai Y, Liu S, Chen Y, Li J, Xie Y, Liu G. A functional polymorphism in the promoter region of microRNA-146a is associated with the risk of Alzheimer disease and the rate of cognitive decline in patients. PLoS ONE. 2014;9(2):e89019.

42. Iwai N, Naraba H. Polymorphisms in human pre-miRNAs. Biochem Biophys Res Commun. 2005;331(4):1439-44

43. Xu T, Zhu Y, Wei Q-K, Yuan Y, Zhou F, Ge Y-Y, Yang J-R, Su H, Zhuang S-M. A functional polymorphism in the miR-146a gene is associated with the risk for hepatocellular carcinoma. Carcinogenesis. 2008;29(11):2126-31.

44. Duval M, Cossart P, Lebreton A. Mammalian microRNAs and long noncoding RNAs in the host-bacterial pathogen crosstalk. In: Seminars in cell \& developmental biology: 2017: Elsevier; 2017: 11-19.

45. Kazemi S, Saidijam M, Hashemi SH, Karami M, Vaisi-Raygani A, Alikhani MY. Analysis of IL-10 and IL-6 gene polymorphisms and their serum levels in patients with brucellosis: a case control study. Immunol Invest. 2016:45(2):107-15.

46. Majzoobi MM, Hashemi SH, Mamani M, Keramat F, Poorolajal J, Basir HRG. Effect of hydroxychloroquine on treatment and recurrence of acute brucellosis: a single-blind, randomized clinical trial. Int J Antimicrob Agents. 2018;51(3):365-9.

47. Miller S, Dykes D, Polesky H. A simple salting out procedure for extracting DNA from human nucleated cells. Nucleic Acids Res. 1988;16(3):1215.

48. Hashemi M, Moradi N, Ziaee SAM, Narouie B, Soltani MH, Rezaei M, Shahkar G, Taheri M. Association between single nucleotide polymorphism in miR-499, miR-196a2, miR-146a and miR-149 and prostate cancer risk in a sample of Iranian population. J Adv Res. 2016;7(3):491-8.
49. Wei L, Zhou Q, Hou S, Bai L, Liu Y, Qi J, Xiang Q, Zhou Y, Kijlstra A, Yang P. MicroRNA-146a and Ets-1 gene polymorphisms are associated with pediatric uveitis. PLoS ONE. 2014;9(3):e91199.

50. Bassam BJ, Gresshoff PM. Silver staining DNA in polyacrylamide gels. Nat Protoc. 2007:2(11):2649.

51. Taganov KD, Boldin MP, Chang K-J, Baltimore D. NF-KB-dependent induction of microRNA miR-146, an inhibitor targeted to signaling proteins of innate immune responses. Proc Natl Acad Sci. 2006;103(33):12481-6.

52. Sheedy FJ. Turning 21: induction of miR-21 as a key switch in the inflammatory response. Front Immunol. 2015;6:19.

53. Maudet C, Mano M, Eulalio A. MicroRNAs in the interaction between host and bacterial pathogens. FEBS Lett. 2014;588(22):4140-7.

54. Das K, Garnica O, Dhandayuthapani S. Modulation of host miRNAs by intracellular bacterial pathogens. Front Cell Infect Microbiol. 2016;6:79.

55. O'neill LA, Sheedy FJ, McCoy CE. MicroRNAs: the fine-tuners of Toll-like receptor signalling. Nat Rev Immunol. 2011;11(3):163-75.

56. Soleimani A, Ghanadi K, Noormohammadi Z, Irani S. The correlation between miR-146a C/G polymorphism and UHRF1 gene expression level in gastric tumor. J Dig Dis. 2016;17(3):169-74.

57. Ramkaran P, Khan S, Phulukdaree A, Moodley D, Chuturgoon AA. miR146a polymorphism influences levels of miR-146a, IRAK-1, and TRAF-6 in young patients with coronary artery disease. Cell Biochem Biophys. 2014;68(2):259-66

58. Kupcinskas J, Wex T, Link A, Leja M, Bruzaite I, Steponaitiene R, Juzenas S, Gyvyte U, Ivanauskas A, Ancans G. Gene polymorphisms of micrornas in Helicobacter pylori-induced high risk atrophic gastritis and gastric cancer PLoS ONE. 2014;9(1):e87467.

59. Hezova R, Kovarikova A, Bienertova-Vasku J, Sachlova M, Redova M, Vasku A, Svoboda M, Radova L, Kiss I, Vyzula R. Evaluation of SNPs in miR-196-a2, miR-27a and miR-146a as risk factors of colorectal cancer. World J Gastroenterol:WJG. 2012;18(22):2827.

60. Cezar-de-Mello PF, Toledo-Pinto TG, Marques CS, Arnez LE, Cardoso CC, Guerreiro LT, Antunes SL, Jardim MM, de Covas CJM, Illaramendi X. Pre-miR-146a (rs2910164 G> C) single nucleotide polymorphism is genetically and functionally associated with leprosy. PLoS Negl Trop Dis. 2014;8(9):e3099.

61. Bogunia-Kubik K, Wysoczańska B, Piątek D, Iwaszko M, Ciechomska M, Świerkot J. Significance of polymorphism and expression of miR-146a and NFkB1 genetic variants in patients with rheumatoid arthritis. Arch Immunol Ther Exp. 2016;64(1):131-6.

62. Xion Y, Chen S, Chen R, Lin W, Ni J. Association between microRNA polymorphisms and humoral immunity to hepatitis B vaccine. Hum Vaccin Immunother. 2013;9(8):1673-8.

63. Song M-y, Su H-j, Zhang L, Ma J-I, Li J-y, Pan K-f, You W-c. Genetic polymorphisms of miR-146a and miR-27a, H. pylori infection, and risk of gastric lesions in a Chinese population. PLoS ONE. 2013;8(4):e61250.

64. Shankaran ZS, Walter CEJ, Ramanathan A, Dandapani MC, Selvaraj S, Kontham SS, Johnson T. microRNA-146a gene polymorphism alters human colorectal cancer susceptibility and influences the expression of its target genes in toll-like receptor (TLR) pathway. Meta Gene. 2020;24:100654.

65. Zhang X, Li Y, Li X, Zhang W, Pan Z, Wu F, Wang C, Chen Z, Jiang T, Xu D. Association of the miR-146a, miR-149, miR-196a2 and miR-499 polymorphisms with susceptibility to pulmonary tuberculosis in the Chinese Uygur, Kazak and Southern Han populations. BMC Infect Dis. 2015;15(1):41

66. Damodaran M, Paul SF, Venkatesan V. Genetic polymorphisms in miR146a, miR-196a2 and miR-125a genes and its association in prostate cancer. Pathol Oncol Res. 2020;26(1):193-200.

67. Cui L, Tao H, Wang Y, Liu Z, Xu Z, Zhou H, Cai Y, Yao L, Chen B, Liang W. A functional polymorphism of the microRNA-146a gene is associated with susceptibility to drug-resistant epilepsy and seizures frequency. Seizure. 2015;27:60-5

\section{Publisher's Note}

Springer Nature remains neutral with regard to jurisdictional claims in published maps and institutional affiliations. 